\title{
Phenotypic and Genotypic Characterization of Carnobacterium divergens Isolated from Refrigerated Tunisian Minced Raw Beef Meat
}

\author{
Thouraya Mokrani ${ }^{1}$, Ines Essid ${ }^{1}$, Mnasser Hassouna1, Lachheb Jihene ${ }^{2}$, Ghram Abdeljalil ${ }^{2}$, and Ahlem Jouini ${ }^{2 *}$
}

${ }^{1}$ Unité de Recherche, Food Science and Technology, Higher School of Food Industries of Tunis (ESIAT), University of Carthage, Tunisia ${ }^{2}$ Laboratory of Epidemiology and Veterinary Microbiology, Pasteur Institute of Tunis (IPT), Université de Tunis El Manar, Tunis, Tunisia

\begin{abstract}
Six psychotropic strains of Carnobacterium divergens were isolated from Tunisian minced raw beef meat packed and stored at $6^{\circ} \mathrm{C}$. They were first identified by biochemical methods. Using biochemical reactions and carbohydrate fermentation before their characterisation by molecular techniques. The strain of Carnobacterium divergens is a nonmotile, Gram-positive psychotropic rod that lacks catalase, oxidase and mannitol. It grows at pH 9.1 (D-MRS agar), but not on acetate agar $(\mathrm{pH} \leq 5.4)$. For all these isolates, the phenotypic identification, using the API $50 \mathrm{CHL}$ system, revealed a variability in the fermentation abilities of some sugars (glycerol, amygdaline, arbutine, D-trehalose and potassium gluconate). Species-specific polymerase chain reaction (PCR) primers were used to ensure identification of these isolated strains at the species level. Moreover, the sequencing of $16 \mathrm{~S}$ rRNA gene confirmed that all the six isolates are identified as $C$. divergens. The Rep-PCR technique was performed to investigate intra-specific diversity within these six strains of $C$. divergens, commonly identified in meat. The Rep-PCR method distinguished the $C$. divergens strains, demonstrating their biodiversity and their evident similarities. BOX and REP primers allowed amplification with $85 \%$ and $80 \%$ similarities between the strains, respectively. The BOXA1R and REP primers were proven to be useful for the differentiation of $C$. divergens strains.
\end{abstract}

Keywords: Carnobacterium divergens; Meat; PCR; 16S rRNA; REPPCR; BOX-PCR

\section{Introduction}

Carnobacterium divergens and C. maltaromaticum are the only bacteria frequently isolated from a large variety of products like meat $[1-5]$, poultry $[6,7]$ and pork meat juice $[8]$.

Carnobacterium divergens are Gram positive, facultative anaerobic, catalase negative, rod shaped lactic acid bacteria (LAB) which produce L (+)-lactic acid from glucose; they are unable to grow on acetate agar but grow in alkaline environment. They are characterized by the presence of meso-diaminopimelic acid in their cell-wall composition $[9,10]$. Besides, they are psychotropic bacteria and tolerant to high pressure freezing/thawing. C. divergens is often found in products whether they are stored aerobically, vacuum packaged, or subjected to modified conditions storage $[1-4,7,11,12]$. Raw meat is an extremely perishable proteinaceous food. Its constitute an ecological niche and a potential risk factor for the spread of these pathogens in the environment [13-23]. However, most lactic acid bacteria group, multiply even under vacuum packaged (VP) conditions, do not constitute, from the beginning, in spoiling the meat quality $[2,24]$. In fact, $C$. divergens have been widely studied in the last two decades as protective cultures, to inhibit pathogenic and spoilage bacteria in food [14-16]. The use of molecular based techniques offers rapid and specific alternatives for species identification. Carnobacterium species form a phylogenetically coherent group which different from other LAB, as shown by $16 \mathrm{SrDNA}$ sequencing [6,17-20]. Repetitive sequence-based polymerase chain reaction (Rep-PCR) technique was widely employed to characterize bacteria and distinguish clonal diversity [21]. Examples of evolutionarily conserved repetitive sequences are BOX, ERIC, REP and (GTG) $)_{5}$ In Tunisia, the industry of meat conservation is not well developed compared to other economically developed countries. Therefore, there is a particular interest in food product conservations and transformation industries. The objective of this study is the isolation and the identification of $C$. divergens from minced raw beef meat in Tunisia packed and stored at $6^{\circ} \mathrm{C}$ using a specific gene and the sequencing of $16 \mathrm{~S}$ rDNA. We identified novel $C$. divergens strains capable to producing bacteriocin variants with a potential application as bio-preservatives. The second purpose was to investigate whether
Rep-PCR could be used to analyse such $C$. divergens strains. Besides, two Rep-PCR techniques (BOX and REP-PCR) were compared for their ability to type strains of $C$. divergens and differentiate their genotypes.

\section{Materials and Methods}

\section{Sample preparation and lactic acid bacteria isolation}

Psychotropic LAB strains were isolated from thirty samples of minced raw beef meat packed and stored at $6^{\circ} \mathrm{C}$. The first fifteen meat samples were collected from a market in Tunis and the other ones from a market in Bizerte (North of Tunisia). Strains of psychotropic LAB were isolated on Man Rogosa and Sharpe (MRS) agar (Biokar) adjusted to $\mathrm{pH} 8.5$, with glucose substituted by sucrose and acetate omitted from modified MRS agar $[22,23]$. All the plates were then incubated at $7^{\circ} \mathrm{C}$ for 10 days [24] and at least hundred single colonies were randomly picked from D-MRS agar and sub cultivated in Tryptone Soya Broth. The isolates were then sub-cultivated to purity at least twice on D-MRS and incubated at $30^{\circ} \mathrm{C}$ for $24-48 \mathrm{~h}$.

\section{Phenotypic characterization}

Gram staining, cell morphology, oxidase, catalase and mannitol tests were performed using standard procedures according to the methods and the criteria described by Sharpe [25] and Guiraud [24]. The isolates were further characterized by physiological tests which include growth on acetate agar [26], motility, $\mathrm{CO}_{2}$ production from glucose in D-MRS broth with Durham tubes [27] and oxide fermentation. The ability to ferment carbohydrate substrates was studied using API 50 CHL system

*Corresponding author: Ahlem Jouini, Laboratory of Epidemiology and Veterinary Microbiology, Pasteur Institute of Tunis, 13 Place Pasteur- BP 74, 1002 BelvédèreTunis, Tunisia, Tel: 216- 71783 022; E-mail: ahlem.jouini@pasteur.rns.tn

Received March 24, 2018; Accepted March 29, 2018; Published April 03, 2018

Citation: Mokrani T, Essid I, Hassouna M, Jihene L, Abdeljalil G, et al. (2018) Phenotypic and Genotypic Characterization of Carnobacterium divergens Isolated from Refrigerated Tunisian Minced Raw Beef Meat. Gene Technol 7: 144 doi: 10.4172/2329-6682.1000144

Copyright: $\odot 2018$ Mokrani T, et al. This is an open-access article distributed under the terms of the Creative Commons Attribution License, which permits unrestricted use, distribution, and reproduction in any medium, provided the original author and source are credited. 
(BioMérieux, France). The computer program APIWEB database identification software (BioMérieux) was used to interpret the results. The isolates were stored at $-80^{\circ} \mathrm{C}$ in Tryptone Soya Broth supplemented with $20 \%$ glycerol as a cryoprotective agent for further analyses.

\section{Molecular identification}

DNA isolation: Bacterial genome DNA was extracted using Onetube Bacterial Genomic DNA Extraction Kit (BIO BASIC CANADA INC). A $0.2 \mathrm{ml}$ volume of fresh overnight culture was transfered into a microcentrifuge tube and centrifuged at $10,000 \times \mathrm{g}$ for 30 seconds. The pellet was lysed by adding a lysis-buffer containing proteinase $\mathrm{K}$. The sample was incubated at $65^{\circ} \mathrm{C}$ for 5 min to which a Universal Buffer NST was added. The DNA concentration was measured using a Nanodrop photometric apparatus (Thermo Scientific).

\section{PCR amplification}

All used primers were obtained from a commercial supplier (Cartha Genomics Advanced Technologies-Tunisia). A universal forward primer, 27f 5'-AGAGTTTGATCMTGGCTCAG-3', and a reverse primer, Cdi 5'-GCGACCATGCGGTCACTTGAA-3', were used to amplify a small target region (198-199 bp) of the 16S rDNA of Carnobacterium divergens [21]. The PCR mixture $(50 \mu \mathrm{l})$ contained $5 \mathrm{U} / \mu \mathrm{l}$ KAPA Taq DNA Polymerase, 10X KAPA Taq Buffer, $10 \mathrm{mM}$ dNTPs, $10 \mu \mathrm{M}$ forward and reverse primer, $2 \mu \mathrm{l}$ genomic DNA and enough sterile deionized water to bring the volume to $50 \mu \mathrm{l}$. The mixture was subjected to an initial denaturation step of $3 \mathrm{~min}$ at $95^{\circ} \mathrm{C}$, followed by 36 cycles of denaturation for $30 \mathrm{~s}$ at $95^{\circ} \mathrm{C}$, annealing for $30 \mathrm{~s}$ at $55^{\circ} \mathrm{C}$, and extension of $1 \mathrm{~min}$ at $72^{\circ} \mathrm{C}$, and a final extension of 1 min at $72^{\circ} \mathrm{C}$ in a DNA thermal cycler (BIO-RAD T100 ${ }^{\mathrm{TM}}$ ). The reaction mixture was visualized on a $2 \%$ agarose gel in Tris-acetate buffer containing ethidium bromide (Sigma), and photographed with an UV transilluminator (VILBER LOURMAT, France). The molecular sizes of the amplified DNA fragments were estimated by comparison to a 100bp DNA ladder (Neo Biotech). The primers used to amplify the whole 16S rRNA gene were fD1 (5'-AGAGTTTGATCCTGGCTCAG-3') and rD1 (5'- TAAGGAGGTGATCCAGCC-3') [28,29]. The PCR amplified DNA fragments contained the complete 16S rRNA gene; amplification steps consisted of a $60 \mathrm{~s}$ denaturation at $95^{\circ} \mathrm{C}$, a $60 \mathrm{~s}$ annealing at $56^{\circ} \mathrm{C}$ and a 90 s extension at $72^{\circ} \mathrm{C}$. The first cycle was preceded by incubation for $5 \mathrm{~min}$ at $94^{\circ} \mathrm{C}$. After 35 cycles, a final 7 min extension step at $72^{\circ} \mathrm{C}$ was realized. The molecular sizes of the amplified DNA fragments were estimated by comparison to a $1 \mathrm{~Kb}$ DNA ladder (Thermo Scientific Gene Ruler).

\section{Sequencing and identification of the species}

All sequencing reactions were performed in the sequencing unit of "Institute Pasteur of Tunis". The nucleotide sequence of the amplified 16S rRNA gene was determined with an ABI PRISM 3500 Genetic Analyzer (Applied Biosystems using the Big Dye terminator v.3.1 Cycle Sequencing Kit. Anticipated errors of PCR and sequencing reactions were avoided by sequencing both DNA strands. The BLAST algorithm was used to determine the most related sequence relatives in the NCBI nucleotide sequence database (http://www.ncbi.nlm.nih.gov/ BLAST).

\section{Rep-PCR analysis}

The repetitive sequence-based oligonucleotide primers (Cartha Genomics Advanced Technologies-Tunisia) used were BOXA1R (5'-CTACGGCAAGGCGACGCTGACG-3') and REP (REP1R: 5'-IIIICGICGICATCIGGC-3', REP2I: 5'-ICGICTTATCIGGCCTAC-3'), each with their specific annealing temperature $\left(1 \mathrm{~min}\right.$ at $40^{\circ} \mathrm{C}$ for REP primers and $1 \mathrm{~min}$ at $52^{\circ} \mathrm{C}$ for $\mathrm{BOX}$ primer). Amplification was car- ried out in a $25 \mu \mathrm{l}$ reaction volume, containing $25 \mu \mathrm{M}$ primer, $5 \mathrm{U} / \mu \mathrm{l}$ KAPA Taq DNA Polymerase, 10X KAPA Taq Buffer, $10 \mathrm{mM}$ dNTPs, $25 \mathrm{mM} \mathrm{MgCl}, 5 \mu \mathrm{l}$ genomic DNA and enough sterile deionized water to bring the volume to $25 \mu \mathrm{l}$. The PCR reactions were performed with an initial denaturation step $\left(95^{\circ} \mathrm{C}, 7 \mathrm{~min}\right)$, followed by 35 cycles of denaturation $\left(90^{\circ} \mathrm{C}, 30 \mathrm{~s}\right)$, annealing (variable temperature, $1 \mathrm{~min}$ ) and extension $\left(65^{\circ} \mathrm{C}, 8 \mathrm{~min}\right)$, and a single final extension step $\left(72^{\circ} \mathrm{C}, 16\right.$ $\mathrm{min})$ [21]. The amplified fragments were fractionated on a $1 \%$ agarose gel during $2-3 \mathrm{~h}$ at a constant voltage of $80 \mathrm{~V}$ in $1 \mathrm{X}$ TAE and $0.5 \mu \mathrm{g} / \mathrm{ml}$ ethidium bromide. The Rep-PCR genomic fragments were visualised after staining with ethidium bromide under ultraviolet light, followed by digital capturing of the image using a CCD camera and storage as a tiff file. The resulting fingerprints were analysed using FPQuest ${ }^{\mathrm{TM}}$ software. The similarities among profiles were calculated using the Pearson correlation. Dendograms were constructed using the Unweighted Pair Group Method with Arithmetic Mean (UPGMA).

\section{Results}

\section{Phenotypic identification of isolates}

Two hundred and fifty suspected bacteria were isolated on D-MRS agar from the 30 samples of minced raw beef meat packed and stored at $6^{\circ} \mathrm{C}$. Those having the following characters: rod shaped cells, Gram positive, oxidase negative, catalase negative strains. Only sixty isolates were retained. Biochemical identification using the API $50 \mathrm{CH}$ system showed that only six strains were identified as $C$. divergens (Table 1 ). These isolates showed differences in their fermentation abilities of some sugars. These differences were related to fermentation of glycerol, amygdaline, arbutine, D-trehalose and potassium gluconate (Table 1). The six isolates of $C$. divergens strains were non-motile, facultative anaerobic bacteria, unable to grow on acetate agar and produce $\mathrm{CO}_{2}$ from glucose.

\section{Molecular identification by and sequencing analyses}

For their molecular identification, the six isolates were contained a 199 bp fragment specific to the $C$. divergens strains, with the $27 \mathrm{f}$-Cdi primer pair. The results of the PCR-amplification reactions for presumptive $C$. divergens isolates were consistent with those the biochemical test (Figure 1). Therefore, sequencing of the small target of $16 \mathrm{~S}$ rRNA gene were indicated that the strains $\mathrm{Cd} 1, \mathrm{Cd} 2, \mathrm{Cd} 5$ and Cd6 have a high level of sequence homology (reaching 99\%) with Carnobacterium divergens strain DSM 15683 16S ribosomal RNA gene (NCBI Reference Sequence: NR_113798.1). Strains Cd3 and Cd4 were identified as C. divergens showed 99\% $16 \mathrm{~S}$ rRNA sequence homology with Carnobacterium divergens strain DSM 20623 16S ribosomal RNA gene (NCBI Reference Sequence: NR_044706.2). To ensure their complete identification, the sequencing of the whole 16S rRNA gene of all isolates was performed to further confirm the identities of the six isolates. In fact, the amplification of $16 \mathrm{~S}$ rRNA gene showed the presence of one band at almost $1500 \mathrm{bp}$ (Figure 2). Therefore, after sequencing and comparison with the GenBank database, we found that the six identified isolates of $C$. divergens were displayed $99 \%$ identity with the 16S rRNA gene of Carnobacterium divergens strain DSM 15683 16S ribosomal RNA gene (NCBI ReferenceSequence: NR_113798.1). This is the first report of a molecular approach characterizing $C$. divergens strains from Tunisian minced raw beef meat, taking advantage of the robust sequencing $16 \mathrm{~S}$ rDNA gene.

\section{Rep-PCR fingerprinting of Carnobacterium divergens isolates}

DNA fingerprint, produced by Rep-PCR method, provided a clonal diversity of the $C$. divergens strains previously typed at the species level using 16S rDNA sequencing. Rep-PCR primer set (REP1R-I and 
Citation: Mokrani T, Essid I, Hassouna M, Jihene L, Abdeljalil G, et al. (2018) Phenotypic and Genotypic Characterization of Carnobacterium divergens Isolated from Refrigerated Tunisian Minced Raw Beef Meat. Gene Technol 7: 144. doi: 10.4172/2329-6682.1000144

Page 3 of 5

\begin{tabular}{|c|c|c|c|c|c|c|}
\hline Strain & Cd1(87) & Cd2(99) & $\mathrm{Cd} 3(84)$ & Cd4(98) & Cd5(33) & Cd6(46) \\
\hline Isolation source & $\operatorname{MRM} 1\left(E_{9}\right)$ & $\operatorname{MRM} 1\left(E_{10}\right)$ & $\operatorname{MRM} 1\left(E_{10}\right)$ & $\operatorname{MRM} 1\left(E_{6}\right)$ & $\operatorname{MRM} 2\left(E_{18}\right)$ & $\operatorname{MRM} 2\left(E_{21}\right)$ \\
\hline Gram & + & + & + & + & + & + \\
\hline Catalase & + & + & + & + & + & + \\
\hline Gaz production & - & - & - & - & - & - \\
\hline Growth on acetate agar & - & - & - & - & - & - \\
\hline \multicolumn{7}{|l|}{ Sugars fermented (API $50 \mathrm{CH}$ ): } \\
\hline Glycerol & + & + & + & - & - & + \\
\hline D-Ribose & + & + & + & + & + & + \\
\hline D-Glucose & + & + & + & + & + & + \\
\hline D-Fructose & + & + & + & + & + & + \\
\hline D-Mannose & + & + & + & + & + & + \\
\hline N-Acetylglucosamine & + & + & + & + & + & + \\
\hline Amygdaline & + & - & - & - & + & + \\
\hline Arbutine & + & + & - & + & + & + \\
\hline Salicine & + & + & + & + & + & + \\
\hline D-Celiobiose & + & + & + & + & + & + \\
\hline D-Maltose & + & + & + & + & + & + \\
\hline D-Saccharose(sucrose) & + & + & + & + & + & + \\
\hline D-Trehalose & + & - & - & + & + & + \\
\hline D-Melezitose & + & + & + & + & + & - \\
\hline Gentiobiose & + & + & + & + & + & + \\
\hline Potassium Gluconate & + & - & - & - & - & + \\
\hline \multicolumn{7}{|c|}{$\begin{array}{l}\text { Cd: Carnobacterium divergens. } \\
\text { MRM: sample of "Minced Raw Beef Meat". } \\
\text { MRM 1: samples were taken from market in Tunis; MRM 2: samples were taken from in Bizerte. } \\
\text { E: sample number from } 1 \text { to } 30 . \\
\text { +: positive; -: negative. } \\
\text { None of the strains of Carnobacterium divergens was able to ferment: Erythritol, D-arabinose, L-Arabinose, D-xylose,L-xylose D-adonitol, Methyl-BD-xylopyranoside, } \\
\text { D-galactose, D-sorbose, L-rhamnose, Dulcitol, Inositol, D-manitol, D-sorbitol, Methyl-aD-Mannopyranoside, Methyl-aD-Glucopyranoside,Esculine citrate de fer, D-lactose, } \\
\text { D-melibiose, Inulin, D-raffinose,Amidon, Glycogen, Xylitol, D-Turanose, D-lyxose,D-Tagatose, D-fucose, L-fucose, D-Aarabitol, I-Aarabitol, Potassium2-ketogluconate, } \\
\text { Potassium5-ketogluconate }\end{array}$} \\
\hline
\end{tabular}

Table 1: Origin and biochemical profiles of the six Carnobacterium divergens strains isolated from Tunisian minced raw beef meat packed at $6^{\circ} \mathrm{C}$.

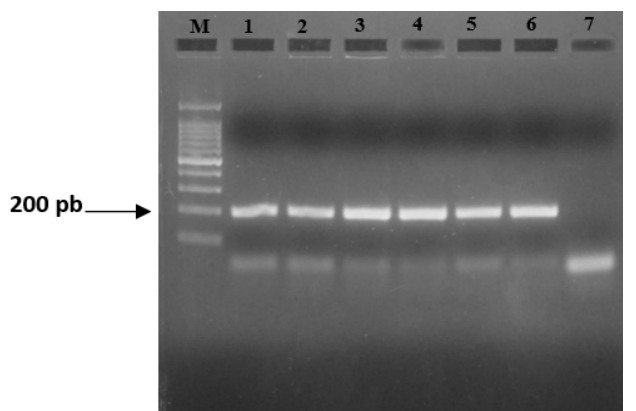

Figure 1: PCR products of Carnobacterium divergens strains, obtained using small 16S rRNA-targeted, species-specific primers (27f-Cdi primer pair); Lane labelled M; 100-bp DNA ladder, lanes (1, 2, 3, 4, 5 and 6); Cd1, Cd2, Cd3, Cd4 $\mathrm{Cd} 5$ and $\mathrm{Cd} 6$, respectively (Cd: Carnobacterium divergens), lane 7; negative control. Lane numbers are indicated in bold.

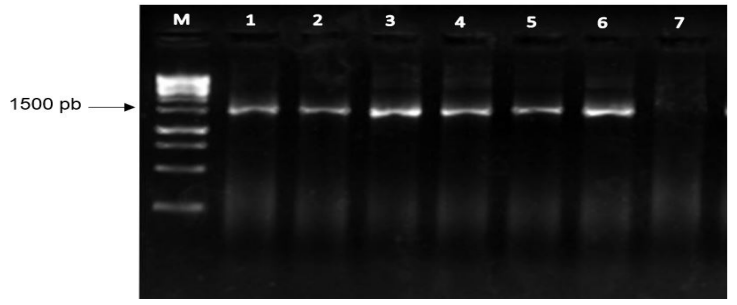

Figure 2: PCR products from Carnobacterium divergens strains, obtained using 16S rRNA-targeted, specific primers (Fd1-Rd1 primer pair); Lane labelled M; 1 Kb DNA ladder, lanes (1, 2, 3, 4, 5 and 6); Cd1, Cd2, Cd3, Cd4, Cd5 and Cd6 respectively (Cd: Carnobacterium divergens), lane 7; negative control. Lane numbers are indicated in bold.
REP2-I primers) and BOXA1R primer were used to compare the clonal diversity of the six closely related strains of $C$. divergens. Each primer generated profiles that vary within the same species and differ in the number and the size of produced bands. Although Rep-PCR revealed similar patterns for the six studied strains, the REP-PCR and BOX-PCR methods showed a better discriminatory power. For $C$. divergens, the isolates were grouped in clusters, demonstrating their biodiversity and, at the same time, their similarities with isolates within the same species. The REP set and the BOX primer, gave successful amplification with a total of 10-12 and 8-12 bands having sizes lying between $250 \mathrm{bp}-3500$ bp and $350 \mathrm{bp}-4500 \mathrm{bp}$, respectively. In comparison with the BOXA1R primer, the REP1R-I and REP2-I primer set clearly generated more bands which allowed easy interpretation and visual differentiation. Each strain gave almost a different REP-PCR fingerprinting although common two intense bands, between $2000 \mathrm{bp}$ and $1500 \mathrm{bp}$, were observed for all six strains, and along with four bands of 400, 800, 900 and $3500 \mathrm{bp}$.

A dendrogram was constructed showing the similarities among the different profiles using the cluster analysis software (Figure 3). At $80 \%$ coefficient value, three distinct clusters could be delineated. According to dendrogram analysis, cluster 1 was grouped two strains of $C$. divergens ( $\mathrm{Cd} 3$ and $\mathrm{Cd} 6)$ with $85 \%$ similarity. Two $C$. divergens (Cd2 and Cd4), sharing 98\% similarity, were clustered with the (Cd1) strain which shares $94 \%$ similarity and all three-formed cluster 2 . The strain (Cd5) formed a distinct cluster with a very low similarity level of $40 \%$. The amplification profiles from the six identified C. divergens gave only a very intense common band, slightly above $1000 \mathrm{bp}$. Three other common bands were also observed, the first one at $350 \mathrm{bp}$, the second between 1000 and $1500 \mathrm{bp}$ and the third one slightly below $2000 \mathrm{bp}$. The 
constructed dendrogram showed the similarities among the different profiles using the cluster analysis software (Figure 4). The six strains were classified according to their BOX-PCR profiles into 4 clusters, at a similarity level of $85 \%$. According to unweighted average method, using amplification profiles obtained for $C$. divergens strains; cluster 1 grouped 2 strains of $C$. divergens (Cd3 and $\mathrm{Cd} 6)$ at $87 \%$ similarity, cluster 2 contained only one $C$. divergens strain $(\mathrm{Cd} 2)$ at a similarity level of $77 \%$, cluster 3 grouped two strains of $C$. divergens $(\mathrm{Cd} 1$ and $\mathrm{Cd} 4$ ) sharing $87 \%$ similarity and cluster 4 contained one strain (Cd5) at a similarity level of $81 \%$.

\section{Discussion}

The diversity of LAB in Tunisian meat products, especially in minced raw beef meat, depends on adventitious microflora present in the meat and meat environment as well as on a number of selective conditions persisting during the manufacturing process. In this study, we report the isolation and identification of $C$. divergens strains. They were isolated from Tunisian minced raw meat packed, stored at $6^{\circ} \mathrm{C}$ then commercialized for human consumption. The catalase negative, oxidase negative and mannitol-negative $C$. divergens isolates, are psychotropic, microaerophilic but oxygen-tolerating bacteria, able to grow in a wide variety of refrigerated raw and processed meat products stored aerobically. They survive freezing and are able to grow in meat after thawing. They are weakly acid tolerant which can be associated with spoilage of refrigerated meat and fish products [6,30,31]. Fresh meat is easily contaminated by the slaughtering process and serves as a substrate for different spoilage and pathogenic bacteria, it harbours non-negligible health risks for all end consumers. However, it could be shown that $C$. divergens strain is frequently present in fresh meat products, but absent in spoiled products [2,32]. Carnobacteria differ from most lactobacilli as they are able to proliferate at low temperatures. In addition, Carnobacteria may be distinguished from lactobacilli by their inability to grow in acetate containing media at $\mathrm{pH}$ values $\leq 5.6$, but are able to grow well in media, at an alkaline $\mathrm{pH}$ around 9.1. The phenotypic tests provided some evidence of metabolic capabilities but there were some problems related to a lack of reproducibility and discriminatory power. None of the phenotypic tests included in the

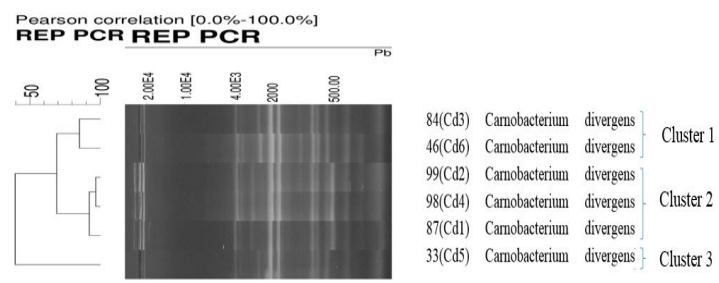

Figure 3: Dendrogram generated from REP-PCR fingerprints of the six $C$ divergens strains obtained from minced raw beef meat. The dendrogram was constructed using the unweighted pair group method using arithmetic averages with correlation levels expressed as percentage.

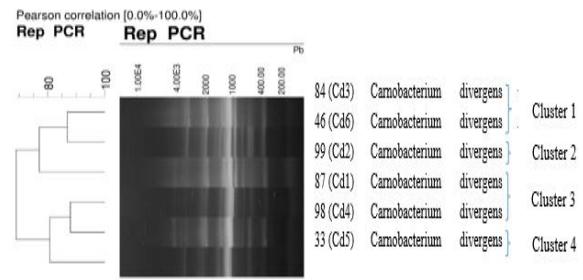

Figure 4: Dendrogram generated from BOX-PCR fingerprints of the six $C$ divergens strains obtained from minced raw beef meat. The dendrogram was constructed using the unweighted pair group method using arithmetic averages with correlation levels expressed as percentage. present study clearly differentiated between $C$. divergens, at the species level. Clearly, C. divergens strains were identified by PCR assays using $16 \mathrm{~S}$ rDNA-directed primers. Therefore, we have used 16S rRNA gene sequencing of all isolated $C$. divergens strains to enhance their detection in minced raw meat. Thus, universal primers (27f-Cdi) were used to amplify target regions (198-199 bp) of the 16S rDNA gene which is considered as a reliable and a useful target for $C$. divergens strain identification. In the present study, we also used the sequencing of the whole $16 \mathrm{~S}$ rRNA gene as described by Kabadjova [33] and confirmed its ability to identify our six isolates of $C$. divergens at the species level. High degrees of similarity (reaching 99\%) of the 16S rRNA gene sequences were observed among the six closely related $C$. divergens. Indeed, these strains demonstrated high identity (99\%) with the $16 \mathrm{~S}$ rRNA gene of C. divergens strain DSM 15683. Based on the phenotypic characters and the API system, our results confirmed the identification of the six selected strains. These strains shared very similar $16 \mathrm{~S}$ rRNA gene sequences (99\%) and demonstrated similar phenotypic traits making it difficult to differentiate them. For this reason, the reproducibility and the discriminatory power of Rep-PCR method in typing strains at the intra-species level, proved to be useful for genotypic fingerprinting and grouping of the $C$. divergens strains. In fact, Rep-PCR using the primers BOXAIR and REP has allowed strain differentiation at the intra-species level $[34,35]$. To date, no studies are available on the use of the RepPCR fingerprinting to discern the intra-species diversity of $C$. divergens isolated from food, especially meat or meat products. In our case, the more important discriminatory power was obtained when using the BOXA1R primer, which generates banding patterns displaying higher intra-species heterogeneity as compared to REP-generated banding patterns. These results confirmed those reported by Masco [34], regarding Bifidobacterium species, even though the REP-PCR profiles were easy to interpret, can sufficiently differentiate the isolates and showed strain specific bands. To our knowledge, no studies have been reported on the use of the BOXA1R primer and the REP primer set for Rep-PCR fingerprinting of $C$. divergens strains. In this regard, we have demonstrated the usefulness of Rep-PCR fingerprinting with the REP and BOX primers for typing $C$. divergens strains. Besides, this study described, for the first time, the presence of $C$. divergens species during the cold storage of Tunisian minced raw beef meat packed and stored at $6^{\circ} \mathrm{C}$, at an industrial scale. The minced raw beef meat contained $C$. divergens species that exist in such environment. Our results of this study brought new information about the diversity of $C$. divergens species in our region. They also suggested that Tunisian minced raw beef meat could be a source of $C$. divergens with considerable differences in respect to acidifying and other technological activities which are being demonstrated. The use of such strains in meat industry could offer great potential for new industrial applications or existing processes. Selected $C$. divergens with slow acidification rate and important technological activities, especially production of bacteriocin, could be used as adjunct cultures for improving the bio preservative, under controlled conditions, of meat product processing.

\section{Conclusion}

The study described, for the first time, the presence of $C$. divergens species during cold storage at $6^{\circ} \mathrm{C}$ of Tunisian minced raw beef meat, which is manufactured on the industrial scale; therefore, they might contain such species found in their environment. The results of phenotypic methods for bacterial identification might be difficult to interpret or ambiguous and required subsequent confirmation. Combination of phenotypic and genotypic methods is considered beneficial for the most reliable identification. Species-specific PCRbased protocols were carried out for the identification of each $C$. divergens species. At the end, the results of our study offered new 
information about the presence of $C$. divergens species in our region. The study recommended that REP-PCR and BOX-PCR are a highly discriminatory technique that permit differentiation at the intraspecies and potentially up to the strain levels. Moreover, isolated and characterized $C$. divergens strains could be eventually used for the construction of starter cultures for bio preservation of minced raw beef meat under controlled conditions in a meat factory.

\section{Funding}

The authors acknowledge financial support for this study from the Tunisian Ministry of Higher Education, Scientific Research and Technology. This work was realized in the Unit of Research 'Science and Technology of Foods' (Research Unit UR04AGR02) at Ecole Supérieure des Industries Alimentaires de Tunis and Institut Pasteur de Tunis (Research Laboratory of Epidemiology and Veterinairy Microbiology LR11IP03)

\section{Acknowledgements}

The contribution of Prof. Imen Echerif, Faculty of Sciences of Tunis, University Tunis El Manar, Tunisia for clustering the fingerprint FPQuestTMsoftware is gratefully acknowledged. The authors also sincerely thank Prof. Imen Echerif for her support and advice. We thank Prof. Abdeljelil Ghram for careful reading of the manuscript.

\section{References}

1. Casaburi A, Nasi A, Ferrocino I (2011) Spoilage-related activity of Carnobacterium maltaromaticum strains in air-stored and vacuum-packed meat. Appl Environ Microbiol 77: 7382-7393

2. Jones RJ (2004) Observations on the succession dynamics of lactic acid bacteria populations in chill-stored vacuumpackaged beef. Int J Food Microbio 90: 273-282.

3. Laursen BG, Bay L, Cleenwerck I (2005) Carnobacterium divergens and Carnobacterium maltaromaticum as spoilers or protective cultures in meat and seafood: phenotypic and genotypic characterization. Syst Appl Microbiol 28 $151-164$

4. Sakala RM, Hayashidani H, Kato $Y$ (2002) Change in the composition of the microflora on vacuum packaged beef during chiller storage. Int J Food Microbio 74: 87-99

5. Samelis J, Kakouri A, Georgiadou KG (1998) Evaluation of the extent and type of bacterial contamination at different stages of processing of cooked ham. $J$ Appl Microbiol 84: 649-660.

6. Barakat RK, Griffiths MW, Harris LJ (2000) Isolation, characterization of Carnobacterium, Lactococcus and Enterococcus spp. from cooked, modified atmosphere packaged, refrigerated, poultry meat. Int J Food Microbiol 62: 83-94.

7. BjÖrkroth J, Ristiniemi M, Vandamme $P$ (2005) Enterococcus species dominating in fresh modified atmosphere-packaged, marinated broiler legs are overgrown by Carnobacterium and Lactobacillus species during storage at $6^{\circ} \mathrm{C}$ Int J Food Microbiol 97: 267-276.

8. Rieder G, Krisch L, Fischer H (2012) Carnobacterium divergens - a dominating bacterium of pork meat juice. FEMS Microbiol let 332: 122-130.

9. Collins MD, Farrow JAE, Phillips BA (1987) Classification of Lactobacillus divergens, Lactobacillus piscicola, and some catalase-negative, asporogenous, rod-shaped bacteria from poultry in a new genus, Carnobacterium. Int J System Bacteriol 37: 310-316.

10. Hammes WP, Hertel C (2003) The genera Lactobacillus and Carnobacterium In: Dworkin M (ed). The Procaryotes: An evolving electronic resource for the microbiological community. New York, Springer-Verlag, 320-403.

11. Susiluoto T, Korkeala H, BjÖrkroth KJ (2003) Leuconostoc gasicomitatum is the dominating lactic acid bacterium in retail modified-atmosphere-packaged marinated broiler meat strips on sell-by-day. Int J Food Microbiol 80: 89-97.

12. Vihavainen E, LundstrÖm HS, Susiluoto T (2007) Role of broiler carcasses and processing plant air in contamination of modified-atmosphere-packaged broiler products with psychrotrophic lactic acid bacteria. Appl Environ Microbio 73: $1136-1145$

13. Pennacchia C, Ercolini D, Villani F (2011) Spoilage-related microbiota associated with chilled beef stored in air or vacuum pack. Food Microbiol 28: 84-93.
4. Brillet A, Pilet MF, Prevost H (2005) Effect of inoculation of Carnobacterium divergens V41, a biopreservative strain against Listeria monocytogenes risk, on the microbiological, chemical and sensory quality of coldsmoked salmon. Int J Food Microbiol 104: 309-324.

15. Tahiri I, Desbiens M, Benech R (2004) Purification, characterization and amino acid sequencing of divergicin M35: a novel class lla bacteriocin produced by Carnobacterium divergens M35. Int J Food Microbiol 97: 123-136.

16. Duffes F, Leroi F, Boyaval P (1999a) Inhibition of Listeria monocytogenes by Carnobacterium spp. strains in a simulated cold smoked fish system stored at $4^{\circ} \mathrm{C}$. Int J Food Microbiol 47: 33-42.

17. Ercolini D, Ferrocino I, Nasi A (2011) Monitoring of microbial metabolites and bacterial diversity in beef stored under different packaging conditions. App Environ Microbiol 77: 7372-7378.

18. Macian MC, Chenoll E, Aznar R (2004) Simultaneous detection of Carnobacterium and Leuconostoc in meat products by multiplex PCR. J Appl Microbiol 97: 384-394.

19. Rachman C, Kabadjova $P$, Valcheva R (2004) Identification of Carnobacterium species by restriction fragment length polymorphism of the 16S-23S rRNA gene intergenic spacer region and species-specific PCR. Appl Environ Microbiol 70: 4468-4477.

20. Scarpellini M, Mora D, Volombo S (2002) Development of genus/speciesspecific PCR analysis for identification of Carnobacterium strains. Curr Microbiol 45: 24-29.

21. Versalovic J, Schneider M, De Bruijn FJ (1994) Genomic fingerprinting of bacteria using repetitive sequence-based polymerase chain reaction. Methods Mol Cell Biol 5: 25-40.

2. Holzapfel W, Gerber ES (1983) Lactobacillus divergens sp nov, a new heterofermentative Lactobacillus species producing $L(+)$ lactate. Systematic Appl Microbiol 4: 522-534.

23. Schillinger U, Holzapfel WHN (1995) The genus Carnobacterium. In: Holzapfe WHN, Wood BJB (ed) In the Genera of Lactic Acid Bacteria. London, Blackie, 307-326.

24. Guiraud JP (1998) Microbiologie Alimentaire. Paris, Dunod.

25. Sharpe ME, Fryer TF (1965) Media for lactic acid bacteria. Laboratory Practice 14: 697-701.

26. Hugas M, Garriga M, Aymerich T (1993) Biochemical characterization of lactobacilli from dry fermented sausages. Int J Food Microbiol 18: 107-113.

27. Greco M, Mazzette R, De Santis EPL (2005) Evolution and identification of lactic acid bacteria isolated during the ripening of Sardinian sausages. Meat Science 69: 733-739.

28. Boulares M, Aouadhi C, Mankai M (2013) Characterisation, identification and technological properties of psychotrophic lactic acid bacteria originating from Tunisian fresh fish. J Food Safety 1745-4565.

29. Matamoros S, Pilet MF, Gigout F (2009) Selection and evaluation of seafoodborne psychrotrophic lactic acid bacteria as inhibitors of pathogenic and spoilage bacteria. Food Microbiology 26: 638-644.

30. Borch E, Kant-Muermans ML, Blixt Y (1996) Bacterial spoilage of meat and cured meat products. Int J Food Microbiol 33: 103-120.

31. Cailliez-Grimal C, Miguindou-Mabiala R, Leseine M (2005) Quantitative polymerase chain reaction used for the rapid detection of Carnobacterium species from French soft cheeses. FEMS Microbiol Lett 250: 163-169.

32. Chenoll E, Macian MC, Elizaquivel P (2007) Lactic acid bacteria associated with vacuum-packed cooked meat product spoilage: population analysis by rDNA-based methods. J Appl Microbiol 102: 498-508.

33. Kabadjova P, Dousset X, Le Cam V (2002) Differentiation of closely related Carnobacterium food isolates based on 16S-23S ribosomal DNA intergenic spacer region polymorphism. Appl Environ Microbiol 68: 5358-5366.

34. Gevers D, Huys G, Swings J (2001) Applicability of rep-PCR fingerprinting fo identification of Lactobacillus species. FEMS Microbiol Lett 205: 31-36.

35. Masco L, Huys G, Gevers D (2003) Identification of bifidobacterium species using rep-PCR fingerprinting system. Appl Microbiol 26: 557-563. 